\title{
0 niezbędności politologicznej interpretacji - subiektywność i narracyjność jako determinanty warsztatu politologa
}

\section{About the Need for Interpretation in Political Sciences - Subjectivity and Narrative as Determinants of the Political Scientist's Workshop}

\begin{abstract}
The author reminds us of the need to view politics both as an objective and subjective phenomenon. He postulates that her study should combine analytical-empirical approach with interpretation. In his understanding, the latter is not identical with the studied reality, but is an attempt to objectify knowledge. The instrumental and mechanistic approach to political processes is completely inadequate, because it ignores the role of emotions, intentions, intelligence, human will and awareness. Political research, however, cannot be limited to interpretation. It is equally important to take into account the structural and material determinants of politics, as well as nature and species. As a result, a conscious researcher has a difficult task to integrate the complex repertoire of methodological tools.
\end{abstract}

Keywords: interpretative approach, integral theory, subjectivity of politics, narrative of politics, political man

Każda małpa może sięgnąć po banana, ale tylko ludzie potrafią sięgnąć gwiazd.

Ramachandran, 2012, s. 28

Badania politologiczne, podobnie jak wszystkie inne strategie poznawcze aspirujące do spełnienia kryterium naukowości, oparte są na wyborach filozoficznych - przede wszystkim ontologicznych i epistemologicznych. W tym zaś względzie założenia dotyczące właściwości polityki jako przedmiotu badań korelują z konkretnymi wyborami metodologicznymi. Nie inaczej jest także z zaproponowa- 
nym ujęciem integralnym, za cel stawiającym sobie próbę przyjęcia perspektywy całościowej i koncentrującym się na wzajemnie dopełniającym charakterze zjawisk i procesów politycznych (Laska, 2017). Nie chodzi tutaj jednak o uzyskanie ontologicznej pewności, ale co najwyżej ograniczonej spójności, determinującej praktykę badań osadzonych na fundamencie ogólnego zrozumienia polityki jako takiej.

Ujęcie integralne wymaga łącznego uwzględnienia zarówno obiektywnych, jak i subiektywno-narracyjnych aspektów polityki. Nie tyle więc idzie o ich pomieszanie, ile o świadome uwzględnienie faktu, że skoncentrowanie się tylko na jednych z nich prowadzi do redukcjonizmu (Searle, 1999, s. 28). W takim ujęciu wspomniane aspekty nie tyleż stanowią alternatywę dającą swobodę i wybór badaczowi, ile składają się na dopełniające, wzajemnie konstytuujące, a przede wszystkim ontologicznie nierozdzielne płaszczyzny przedmiotu badań. Własności strukturalne i materialne składniki kultury, w tym również wytwory polityki, obiektywnie kształtują sytuacje, z którymi mimowolnie konfrontują się podmioty polityczne. Jednocześnie to właśnie te podmioty tworzą owe struktury i wytwory. Wspomniane właściwości mają więc moc generowania zarówno ograniczeń, jak i możliwości działania. Upraszczając, można powiedzieć, że tak jak podmiot kształtuje strukturę, tak i ona kształtuje jego. Nie oznacza to jednak, że w konkretnym momencie historycznym znaczenie jednej ze stron owego sprzężenia nie może być dominujące.

Tymczasem pod koncepcją politologii jako nauki skoncentrowanej jedynie na wykorzystaniu narzędzi analitycznych kryje się wyobrażenie wolnego od wartościowania procesu dociekania przyczyn zjawisk. Efektem miałaby być esencjalistyczna wiedza, która opierając się na eleganckich prawach i teoriach, mogłaby być testowana empirycznie i potwierdzana w obserwacji oraz za pomocą analizy reprezentatywnych danych. Wiąże się to z uznaniem, że istnieje jakaś jedna adekwatna forma reprezentowania rzeczywistego świata znaczeń i przedmiotów polityki. Dominacja kryteriów racjonalności formalnej wyznacza wysoce utylitarny imperatyw poszukiwania zestawu odtwarzalnych reguł i metod, czyli pewnych procedur działania prowadzących do określonych, pożądanych skutków (np. zdobycia władzy). Tak rozumiana teoria, w przeciwieństwie do episteme, ma charakter techniczny i nastawiona jest na zastosowanie (Habermas, 1983, s. 88). Wspierający ją model racjonalności delegitymizuje każdą inną koncepcję, która nie wpisuje się w perspektywę zależności między środkiem a celem, oraz każdą instytucję, która nie posiada funkcjonalnej użyteczności. Ujawniający się w ten sposób politologiczny rozum instrumentalny pociąga za sobą technokratyzację samej polityki (Laska, 2012, s. 52-65).

Jeśli jednak uznać, że polityka to fenomen obiektywny i subiektywny zarazem, to jej badanie wymaga strategii łączącej podejście analityczno-empiryczne z interpretacją, która skądinąd również stanowi próbę obiektywizacji wiedzy. Instrumentalne i mechanistyczne ujęcie procesu politycznego jest całkowicie 
nieadekwatne, gdyż ignoruje istnienie drugiego jej wspomnianego wymiaru, a przede wszystkim emocji, intencji, inteligencji, woli i świadomości człowieka, a zatem zjawisk, których istnienie zostało naukowo udowodnione (Stankiewicz, 2003, s. 212-213). Zasadniczą cechą procesu politycznego jest to, że nie można go wyjaśnić, sprowadzając jego przebieg do etapów technicznej realizacji celu. We wszystkich swych wymiarach świat społeczny jest przynajmniej częściowo indeterministyczny. Ponadto inną jego cechą jest możliwość, a nawet konieczność sporu na temat samych regulatywnych kryteriów wartości wyznaczających cele, co wynika z faktu jego przynależności do sfery ogólnych zagadnień kulturowych (Weber, 2004, s. 137). Z tego względu obiektywizmu jego poznania nie należy sprowadzać jedynie do odtwarzalności pozyskiwanych danych. Prowadzi ono zresztą do ciągłego zawężania zarówno zakresu przestrzennego i czasowego analiz, a wręcz do koncentrowania się jedynie na teraźniejszości. Konsekwencją takiego redukcjonizmu jest wiedza wysoce ograniczona i wycinkowa. Jeśli w ogóle staje się funkcjonalna, to co najwyżej względem bieżącego administrowania, nie zaś polityki jako takiej.

Konieczność badań niekwantyfikowanych wymiarów polityki oznacza, że różne postaci interpretacjonizmu znajdują zastosowanie w przypadku wszystkich pogłębionych analiz politologicznych (Lenk, 1995, s. 135-139). Wynika to z faktu, że zależność między działaniem a rezultatem w polityce ma charakter nie czysto techniczny, lecz przede wszystkim kulturowy. Skuteczność takiego działania nie stanowi prostego odwzorowania zależności między przyczynami i skutkami. Uwarunkowana jest bowiem nie tylko właściwościami formalnymi używanych instrumentów, ale również kulturowym kontekstem działania. Szczególne zaś znaczenie przypada subiektywności i narracyjności wszelkiej polityki.

\section{Subiektywność polityki}

Człowiek jako twórca kultury, w tym polityki, jest jednocześnie jej nosicielem i odbiorcą. Ma ona wymiar czasowy, przestrzenny i stanowi swego rodzaju jego aparat adaptacyjny. W jej ramach także polityka jest narzędziem dostosowania w życiu zbiorowym, zachodzącym w określonym czasie i w konkretnej przestrzeni. Kultura to zbiór przekonań normatywnych i dyrektywalnych, które nie tylko są powszechnie respektowane w danej społeczności, ale tworzą też subiektywno-racjonalne uwarunkowania aktywności człowieka (Nowicka, 2009, s. 53-54). Takie rozumienie zakłada, że wszelkie działania występujące w obrębie danej społeczności, także polityczne, oddziałujące (funkcjonalnie bądź dysfunkcjonalnie) względem jej stanu strukturalnego, mają swoje determinanty subiektywno-racjonalne, zawierające się w systemie przekonań dominujących i respektowanych (należących do kultury owej społeczności). Ludzki umysł ni- 
gdy nie jest pusty, wprost przeciwnie - jest on przepełniony różnorodnymi obrazami, generowanymi w duchu sytuacji, w której znajduje się podmiot (Dziubka, 2014, s. 99).

Subiektywność stanowi warunek wstępny doświadczania kultury, a w jej ramach polityki i z tego względu składa się na zasadniczy przedmiot badań politologicznych. Polityka jako kulturowy wytwór człowieka implikowana jest jego naturalnymi możliwościami, ale i potrzebami oraz ograniczeniami. Wszystkie one mają nie tylko charakter obiektywny, co wynika z gatunkowej specyfiki Homo sapiens, lecz także subiektywny, co oznacza, że mogą być różnie postrzegane i odczuwane - zarówno w zakresie ich świadomości, jak i metod zaspokojenia. Z tego względu w sferze ujawniających się fenomenów politycznych trudno doszukać się prawidłowości zachowania aktorów sceny politycznej. Warunki zewnętrzne wpływają na człowieka za pośrednictwem świadomości i wiedzy, które nie tylko powiązane są z emocjonalnym wymiarem umysłu i jego funkcji poznawczych, ale sprzężone zostają również z procesem wartościowania oraz tworzenia na tej podstawie norm i reguł (Brożek, 2013, s. 46-49).

W realiach układów społeczno-politycznych szczególnie istotne jest sprzężenie między specyfiką istniejących obiektywnie struktur a subiektywną naturą ich twórców. Żadna organizacja czy instytucja społeczna nie posiada samoświadomości, podczas gdy każdy normalny, pojedynczy jej członek jest bytem samoświadomym. Pozwala to zresztą na konstytuowanie się ludzkiej podmiotowości „od wewnątrz” (Dziubka, 2011, s. 23-24). Niezależnie więc od sposobu badawczej konceptualizacji społeczeństwa - jako emergentnej warstwy rzeczywistości bądź jako negocjowanego i obiektywizowanego konstruktu - to, co społeczne różni się od składających się nań elementów tym, że nie posiada samoświadomości. W konsekwencji, zadaniem teoretyków polityki jest uwzględnianie fundamentalnego znaczenia świadomości ludzi składających się na ich przedmiot badań (Dziubka, 2015a, s. 115).

Zasadniczą rolę odgrywa świadomość potrzeb i interesów politycznych oraz funkcjonalnych względem nich dóbr. Bez względu na poziom jej prawdziwości czy fałszywości determinuje ona aktywność polityczną (Karwat, 1980, s. 274). Główną jej funkcją jest warunkowanie doboru celów i sposobów ich realizacji w ramach panujących uwarunkowań. Świadomość ma tym samym wpływ na utrzymanie i reprodukowanie pewnych instytucji i stosunków politycznych, ale może też prowadzić do ich zanegowania, wyeliminowania i zastąpienia innymi (Blok, 1998, s. 123). Istotne znaczenie przypada tutaj refleksyjności podmiotu, w ramach której dookreślone zostają preferencje w świetle zachodzących okoliczności. Ich ocena następuje poprzez subiektywne rozważania i odwołanie do odczuwanych emocji oraz opisów na temat tego, jaki kierunek działania podjąć w obliczu artykułowanych potrzeb i interesów, ograniczeń i możliwości (Archer, 2013, s. LV-LXIV). 
Perspektywa taka uwzględnia znaczenie jednostkowej odrębności, co oznacza, że nawet te podmioty, które zajmują podobne pozycje społeczne, nie będą działać w taki sam sposób w podobnych uwarunkowaniach strukturalnych. Nie da się więc ich postępowania $\mathrm{w}$ pełni przewidzieć i to przede wszystkim $\mathrm{z}$ tego względu analiza polityki wymaga docenienia owej siły subiektywności - zarówno w wymiarze ukrytych intencji, jak i ujawniającej się indywidualnej sprawczości (Archer, 2007, s. 16).

Zależności strukturalne świadomości powodują jednak, że interpretacja empirycznych przejawów samostanowienia, autodeterminacji i poczucia sprawstwa musi także uwzględniać determinację fizyczno-materialistycznych właściwości życia organicznego. Istotną rolę odgrywa tutaj cała gama nie tylko kulturowych, ale i fizycznych oraz neurofizjologicznych czynników przyczynowych. Ich emergentne skutki oddziaływania nie układają się w następujące po sobie ciągi stanów świadomości i zachowań, a styl myślenia i działania podmiotu jest refleksem charakterystycznego dla niego sposobu przetwarzania informacji. Neuronauka dostarcza wiedzy o tego typu wielostronnych uwarunkowaniach świadomości ludzkiej. Jak wskazuje Kazimierz Dziubka, niedorzecznością byłoby zatem oczekiwanie, iż ewolucyjnym przeznaczeniem człowieka ,jest przetwarzanie informacji bodźcowej w jednoznaczne, wolne od egzystencjalnych domieszek reprezentacje mentalne i afektywno-emocjonalne polityczności i polityki” (Dziubka, 2015a, s. 118).

Badania polityki nie mogą więc ignorować istnienia żywego i kreatywnego aktora, który za pośrednictwem indywidualnego rozumienia i interpretacji tworzy jej obraz (Warchał, 2005, s. 63-75). Jak wskazuje Charles Taylor, powstaje w ten sposób szersze „imaginarium społeczne”, na które składa się to, jak „ludzie wyobrażają sobie swoją społeczną egzystencję, jak przystosowują się do innych, jak toczą się sprawy między nimi i bliźnimi; to także oczekiwania, które zwykle się spełniają, oraz głębsze normatywne koncepcje i obrazy leżące u ich podstaw" (Chmielewski, 2011, s. 41-58). Rzeczywistość polityczna istnieje więc niejako podwójnie, a mianowicie na zewnątrz i wewnątrz działającego podmiotu. Jej subiektywne obrazy obejmują mentalne reprezentacje, będące wytworem indywidualnego umysłu oraz oddziaływań kontekstowych, wynikających z doświadczania otoczenia (Dziubka, 2015b, s. 61-63).

Podstawowe znaczenie dla polityki jako zjawiska subiektywnego ma jej płaszczyzna aksjonormatywna. Dotyczy to zarówno artykułowanych publicznie systemów wartości, jak i legitymizujących strukturę polityczną narracji ideowych. Ponadto stanowi ona również odniesienie wobec kryteriów ustalania pożądanych społecznie dóbr, a także determinuje reguły ich kreacji, rozdziału i ochrony. Staje się więc punktem odniesienia dla wartościowania nie tylko struktury, czyli politycznej formy, ale i procesu, czyli politycznej treści. Interpretacje idei zawarte w programach czy doktrynach politycznych ukierunkowują i uzasadniają poczynania podmiotów, $w$ tym też decydentów czy zorganizowanych grup 
interesu. Niezbędność tego typu narracji wynika z moralno-emocjonalnych fundamentów ich podmiotowości, determinowanych właściwościami ludzkiego umysłu, a przede wszystkim jego normatywnej specyfiki (Brożek, 2013, s. 4849; Kurek, 2016, s. 16-21).

W tym kontekście zasadnicze wyzwania dla interpretacyjnej strategii badawczej politologów wynikają z dynamiki innowacji pojęciowych, które pojawiają się w ramach procesów ideotwórczych. W kreowaniu nowych znaczeń szczególną rolę odgrywają metafory. Będąc wytworem wyobraźni i kreatywności, otwierają dostęp do nowego rozumienia doświadczeń i definiowania rzeczywistości. W większości przypadków nie chodzi o prawdę czy fałsz, lecz o percepcję i wnioski, jakie z takich metaforycznych ujęć wynikają. Mogą one bowiem sankcjonować określone działania, a tym samym wzmacniać poziom integracji odbiorców i mobilizować ich do wspólnego działania. Ideologie fundowane są często na takich katachrezach lub - jak to nazywa George Lakoff - „ekscytujących metaforach". Są one bowiem wystarczająco nośne, aby mobilizować do działania, i dostatecznie niejasne, by integrować wokół siebie szerokie spektrum społecznej energii (Lakoff, Johnson, 2010, s. 191-198, 212-213, 302-303). Kompleksowe poznanie i zrozumienie procesów politycznych wymaga uwzględnienia ich roli w procedurze badawczej, co świadomego politologa zmusza do poszerzenia wykorzystywanego instrumentarium.

Podsumowując, należy więc podkreślić, że praktyka polityczna uwarunkowana jest podwójnie. Po pierwsze, funkcjonalnie bądź dysfunkcjonalnie, co można określić w wymiarze obiektywnym (przedmiotowym, materialnym), sprowadzającym się do kompleksu rezultatów działania. Składają się na niego struktury polityczne, przede wszystkim instytucje, reguły, praktyki i wszelkie formy organizacji związku politycznego, w tym aparatu władzy. Po drugie zaś, determinowana jest także kulturowo, co sprowadza ją do wymiaru subiektywno-racjonalnego (podmiotowego, humanistycznego, świadomościowego, motywacyjnego) (Banaszak, Kmita, 1994, s. 43). Choć powiązany jest z indywidualną kreatywnością i sprawczością, a co za tym idzie - ujawnianymi systemami wartości, to może być również ukryty i całkowicie nieartykułowany (Searle, 1999, s. 30 i n.). Z badawczego punktu widzenia rozróżnienie obiektywnej i subiektywnej płaszczyzny polityki wydaje się o tyle istotne, że pociąga za sobą konieczność dostosowania odpowiednich narzędzi do poznania każdej z nich oraz integralnego i spójnego powiązania uzyskanych w ten sposób wyników badań.

Jeśli wizja polityki, a w efekcie jej praktyka są subiektywnie konstruowane, to celem badań politologicznych winno być dotarcie do wiarygodnych interpretacji tychże konstrukcji. Ich analiza powinna się opierać na przekonaniu, że jeżeli ludzie postrzegają w pewien sposób sytuację i definiują ją jako realną i polityczną, to jest ona realna i polityczna w swoich konsekwencjach - niezależnie od tego, czy ta definicja sytuacji odpowiada prawdzie obiektywnej. Ostatecznie bowiem partykularna perspektywa należąca do świata wewnętrznych przeżyć 
emocjonalno-moralnych także obiektywizuje się w ramach określonych norm i instytucji (Chmielewski, 2011, s. 41-58). Z tego względu to, co aktor polityczny uznaje za element rzeczywistości politycznej, oraz to, jak siebie w niej lokalizuje, stanowi równie istotny przedmiot badań, jak i to, co obiektywnie w niej zaistnieje. Tutaj jednak potrzebna jest o wiele większa pokora w oczekiwaniu jednoznacznych wyjaśnień, a zrozumienie zjawiska może się oprzeć jedynie na spełniającej kryteria naukowości interpretacji.

Nie tylko więc politykę, ale i politologię należy uznać za sferę odkrywania, uszczegółowiania oraz artykułowania wyobrażonego porządku interpretacyjnego (Harari, 2017, s. 41-51). Na jego bazie może powstać przekonanie o sensowności organizacji życia zbiorowego, łączące rutynowe wydarzenia z przekonaniami dotyczącymi natury rzeczy. Stanowi on fundament dla potencjału prawomocności związku politycznego oraz ludzi sprawujących w nim władzę. Polityki nie da się zatem zrozumieć, sprowadzając ją do kategorii instytucji, władzy, interesów, wpływów czy przetargów, nie biorąc jednocześnie pod uwagę towarzyszących im narracji i argumentacji.

Odkrycie oraz interpretacja świata wyobrażonego, obiektywizującego się w praktykach politycznych, wymagają skoncentrowania się na debacie publicznej. Jej skala i otwartość zależą od typu reżimu, a więc zarówno ustroju, jak i kultury politycznej. W skrajnym przypadku może być całkowicie ograniczona wolą hegemona i zachodzić co najwyżej w niejawnych kanałach sfery prywatnej. Jej podstawową funkcją jest ustalenie norm, które w danym momencie określają, jakie zjawiska i problemy należy uznać za kwestie polityczne. Innymi słowy, chodzi o wskazanie tego, co i dlaczego wymaga kreacji, określonej dystrybucji bądź ochrony w zakresie dóbr publicznych i zasobów wspólnych. Normy te nie są ani dane, ani niezmienne, lecz same w sobie stanowią funkcję procesu politycznego. Staje się on zatem mechanizmem selekcji tych spośród konkurencyjnych znaczeń interesów i wartości, które w danym momencie najlepiej odpowiadają preferencjom podmiotów dominujących w otoczeniu społecznym (Majone, 2004, s. 243-245). Jest to proces złożony i trudny do badawczego uchwycenia, gdyż na owej agorze „nigdy nie mamy do czynienia z czystym echem, ale plotkami, zgęstnieniami, przemieszczeniami, akumulacjami, uproszczeniami, objazdami, przekształceniami - z wysoce skomplikowaną chemią sprawiającą, że jedność reprezentuje całość, a czasem $\mathrm{z}$ innego rodzaju procesem chemicznym, równie złożonym, w rezultacie którego (niekiedy) całość jest posłuszna jednostce" (Latour, 2013, s. 309). Ujawniająca się tu polityka to dyskursywna sfera dyssensu, która przyjmuje postać aktywności dramatycznej, ponieważ zawsze oznacza proces wyboru między nieprzystającymi do siebie i niekwantyfikowanymi dobrami, który i tak całkowicie nie wyeliminuje konfliktu (Berlin, 1991, s. 186). 


\section{Narracyjność polityki}

Interpretacja i zrozumienie tego typu procesów wiąże się z uwzględnieniem dyskursywnego i narracyjnego charakteru polityki. Już etymologia terminu „dyskurs" mówi wiele na temat jego specyfiki. Wywodzi się on z języka łacińskiego od słów discursus, discurere, co oznacza bieganie w różne strony, rozproszenie, spieszenie, ale i dyskutowanie (Kumaniecki, 1986, s. 166). W znaczeniu słownikowym natomiast „dyskursywny” to postępujący etapami w swoim rozumieniu i refleksyjny (Julia, 1998, s. 87). Dyskurs pojmowany jest tu jako zespół reguł dochodzenia do twierdzeń prawdziwych nie w drodze apodyktycznych twierdzeń, lecz dopuszczenia i przemyślenia wielu głosów (Krakowiak, 2008, s. 51; van Dijk, 2001, s. 12). Według tradycji lingwistycznej kategoria ta służy do określenia jednostki językowej większej aniżeli pojedyncze zdanie, a przy tym uporządkowanej oraz takiej, w której przejawia się podmiot mówiący wraz z siecią relacji łączących go z adresatem wypowiedzi (Nunan, 1993, s. 5; Grabias, 1997, s. 264). Dyskurs oznacza tutaj „język w użyciu”. W ujęciu interdyscyplinarnym stanowi jednak zjawisko o wiele szersze, co jest zgodne z wcześniej przytoczoną etymologią. Dyskurs to swoiste ramy myślenia i argumentowania w danym obszarze życia społecznego, które określone są przez wspólny przedmiot mowy i przez jej regularność oraz relacje do innych dyskursów (Giddens, 2007, s. 720; Fleischer, 2002, s. 371 i n.). Ich ujawnienie następuje za pośrednictwem interakcji komunikacyjnych, które polegają na negocjowaniu znaczeń. Oznaczają otwarte połączenie wypowiedzi z określonymi warunkami jej powstania, co w definicji dyskursu pozwala wyróżnić funkcję kształtowania tożsamości (Foucault, 1977, s. 57). Choć jednak dyskurs stanowi strukturę determinującą działania jednostek, to nie jest w tym całkowicie autonomiczny. Właściwsze jest postrzeganie go jako struktury, w obrębie której podmioty rodzą się i która jest potem tłem dla ich przekonań i działań, nie determinując ich w pełni. Jego składowe są bowiem dynamiczne i ewoluują, a wyłaniając się z praktyk społecznych, zawsze sytuują się w kontekście historycznym (Bevir, Rhodes, 2006, s. 139-141).

W zaproponowanym znaczeniu narracja jest co najwyżej elementem dyskursu, albo inaczej mówiąc: zdarzeniem dyskursywnym, czyli zamkniętym przekazem znaczenia wyartykułowanego zarówno na gruncie języka w zdaniu, jak i poprzez kontekst, w którym zostało wypowiedziane. Z języka łacińskiego narratio, czyli opowiadanie, wskazuje na aspekt fabuły. Biorąc to pod uwagę, narracja to całościowy sposób językowego ujmowania przedstawianych w tekście zdarzeń. Ma strukturę zamkniętą i linearny charakter, co oznacza, że budowana jest według następstwa czasowego (Krakowiak, 2008, s. 50-51).

Zrozumienie przez człowieka otaczającej go rzeczywistości, w tym polityki, wymaga naturalnej dla niego formy narracji, czyli swego rodzaju opowiadania. Stworzenie takiej konstrukcji możliwe jest dzięki wrodzonym właściwościom ludzkiego umysłu, który jest zdolny do abstrakcyjnej refleksji. Narracyjna 
i abstrakcyjna interpretacja konstytutywnych dla polityki zjawisk i problemów strukturalizuje doświadczenie w kategoriach intencji jednostek i grup. Z kolei niemożność takiego ustrukturalizowania doświadczeń negatywnie odbija się na ich funkcjonowaniu, nie tylko ogranicza możliwość adaptacji do tego, co zachodzi, ale często też całkowicie paraliżuje podmiotową kreatywność (Nelson i in., 1989, s. 27-121).

Bez względu na poziom otwartości czy instytucjonalizacji, który zależy od typu reżimu politycznego, debata publiczna mobilizuje wiedzę, doświadczenie i zainteresowanie otoczenia. Szczególnej dynamiki nabiera w systemach, w których funkcjonuje zbiorowy podmiot decydowania. Jej przedmiotem staje się przede wszystkim dookreślenie dominującej narracji o sprawiedliwości, a więc pewnej opowieści o tym, jak kreować, chronić i dzielić dobra publiczne oraz zasoby wspólne. Wyjątkowo silne napięcia i konflikty argumentacji pojawiają się tu na styku polityki, nauki, religii, techniki i ekonomii. Ujawniają się szczególnie w reżimach otwartych, na przykład liberalno-demokratycznych, gdzie szeroki zakres wolności powoduje, że każda z wysuwanych ofert ma swój język, własne kategorie oraz koncepcję prawdy adekwatną do reprezentowanej dziedziny. W takiej sytuacji istotna rola przypada retoryce jako sztuce przekonywania do swoich racji. W wolnej debacie, a raczej jej typie idealnym, perswazja staje się dwukierunkową wymianą, metodą wzajemnego przekonywania, ale i uczenia poprzez dyskurs. Większość ocen wartościujących formułowana jest właśnie $\mathrm{w}$ trakcie takiej komunikacji.

Argumentacja polityczna różni się od formalnego dowiedzenia prawdziwości pod trzema istotnymi względami. Po pierwsze, dowód możliwy jest jedynie w ramach sformalizowanego systemu aksjomatów i zasad wnioskowania. Argumentacja nie wychodzi zaś od aksjomatów, lecz od opinii, wartości lub spornych punktów widzenia; wykorzystuje wnioskowanie logiczne, ale nie kończy się na dedukcyjnych systemach formalnych twierdzeń. Po drugie, dowiedzenie słuszności ma na celu przekonanie osób, które posiadają wymaganą wiedzę specjalistyczną, podczas gdy argumentacja zawsze skierowana jest do konkretnych odbiorców i stara się uzyskać lub zwiększyć poparcie dla tez przedstawionych do aprobaty. Ponadto argumentacja nie służy uzyskaniu czysto intelektualnej zgody, lecz pobudzeniu do działania lub przynajmniej wywołaniu gotowości działania w odpowiednim momencie (Perelman, 1982, s. 4-6). Względy te nie uzasadniają postrzegania jej jako irracjonalnej czy zaledwie racjonalizującej, gdyż polityka wymaga uwzględnienia innej formy racjonalności aniżeli instrumentalna i to właśnie ta jej specyfika powoduje, że interpretacja jako strategia poznawcza politologa staje się niezbędnym elementem jego metodologicznego oprzyrządowania.

Integralne ujęcie polityki odrzuca jednostronny pogląd decyzjonistyczny, że przy jasno sprecyzowanych celach i wystarczających informacjach zawsze istnieją prawidłowe rozwiązania problemów politycznych i można je znaleźć za 
pomocą kwantyfikowalnej analizy (Stankiewicz, 2003, s. 198). Odrzucone więc zostaje przekonanie, że źródłem optymalizacji politycznej jest dominacja scjentystycznie pojmowanej wiedzy i adekwatnych względem niej kryteriów racjonalności. Właściwsze wydaje się nawiązanie do tradycji filozoficznej, która definiuje racjonalność nie w kategoriach instrumentalnych, lecz jako zdolność przedstawienia możliwych do przyjęcia przyczyn wyborów i działań. Proponowane ujęcie rozumności nie marginalizuje znaczenia wartości, poglądów i opinii, a przede wszystkim wspomnianej argumentacji, która w polityce pełni zasadniczą rolę.

Już Arystoteles twierdził, że temu, co pożądane w kontekście przypadkowej i zmiennej praktyki politycznej, brakuje zarówno ontologicznej stałości, jak i logicznej konieczności. Z tego względu podstawą namysłu polityka nie powinna być racjonalność kładąca nacisk na realizację określonego i stałego celu, który jest zewnętrzny wobec etapów racjonalnego procesu i nie podlega krytyce. Sfera teleologiczna powinna stanowić raczej przedmiot krytycznej refleksji, w ramach której cele nie są uznawane za stałe i zewnętrzne wobec analizy, ale za wybieralne i kwestionowalne. Ich wybór stanowiłby wówczas efekt dłuższego procesu uzgadniania różnych narracji, a w ich ramach określonych argumentów i preferencji. Wraz z postępującą otwartością tego procesu rosłaby jednocześnie szansa odpowiedniego wybrzmienia głosu podmiotów społecznych i reprezentujących ich instytucji. Mogłyby w ten sposób zaistnieć warunki brzegowe dla politycznej optymalizacji działań.

Wdrażanie racjonalnej polityki nie oznacza także wcześniejszej analizy wszystkich możliwych następstw potencjalnych działań. Nie chodzi tu zresztą o fakt, że nie byłaby ona pożądana, ale raczej o to, że ze względu na upływ czasu, dynamikę kontekstu, brak pełnej informacji, a przede wszystkim specyfikę samej polityki jest ona po prostu niemożliwa. Analiza ta zachodzi więc w formie niepełnej i musi uwzględniać czynnik niepewności. Ponadto posługiwanie się argumentami adekwatnymi dla odniesienia celowo-racjonalnego ma ograniczony potencjał kreowania poparcia i legitymizacji. Spójna wewnętrznie polityka wymaga jak najściślejszego dostosowania jej do zmieniającego się otoczenia, co z kolei oznacza konieczność uwzględniania także innych niż techniczne i prakseologiczne kryteriów optymalności decyzji. Wciąż potrzeba nowych argumentów i dlatego tak istotny staje się wybór odpowiedniej narracji, czyli perswazyjnie sformułowanej całościowej kombinacji faktów, wartości i metod, które zwiększą szanse na przekonanie grupy odbiorców.

Z tego też względu przyjmowanie idealnych czy uniwersalnych standardów w ocenie lub porównywaniu alternatywnych instrumentów polityki jest błędem. Standardy muszą się odnosić do specyficznego i przygodnego kontekstu, w którym instrumenty są stosowane. Obejmuje on wartości, normy, percepcję i ideologię, co w konsekwencji powoduje, że względy techniczne są niewystarczające jako adekwatne kryteria wyboru. Mobilizacja i budowa stabilnych koalicji wokół narracji wymagają argumentacyjnego poruszenia kwestii instytucjonal- 
nych, społecznych i aksjologicznych (Majone, 2004, s. 243-245). Formalna analiza ujawnia tutaj jedynie granice tego, co jest teoretycznie możliwe do osiągnięcia. Z kolei dla ustalenia, co w konkretnej sytuacji może być osiągnięte, politycy muszą uwzględnić większość wskazanych powyżej czynników oraz nieprzewidywalne w pełni próby manipulowania nimi (Majone, 2004, s. 223-224). O kwestiach wymagających inicjatywy politycznej można więc powiedzieć, że mają wiele możliwych rozwiązań albo też żadnego rozwiązania, że można je rozstrzygać bądź porozumieć się czy zawrzeć kompromis, ale żadna $\mathrm{z}$ tych reakcji nie będzie w pełni doskonała. Konflikty interesów i tak pozostaną, a co najwyżej w miejsce jednych pojawią się inne. Niemniej dzięki politycznej interwencji, decyzji oraz towarzyszącej jej narracji możliwe jest, że staną się mniej nabrzmiałe i będą zachodzić w sposób kontrolowany, co pozwoli na względny porządek i poczucie społecznego bezpieczeństwa. Procesy polityki jako praktyki neutralizowania antynomiczności życia społecznego będą się jednak toczyły dalej, odnosząc się do konfliktogennego zderzenia potrzeb w perspektywie ograniczonej ilości dóbr publicznych oraz zasobów wspólnych. Ich badanie nie może prowadzić do jednoznacznych i pewnych wyjaśnień, ale co najwyżej do mniej lub bardziej przekonujących prób zrekonstruowania i nadania interpretacyjnego znaczenia uchwyconych zjawisk.

W związku z powyższym adekwatna forma odnoszenia się do prawdy w polityce polega na poddawaniu artykułowanych narracji/interpretacji intersubiektywnemu sprawdzeniu, czyli na publicznym ich ścieraniu się i konkurencji oraz weryfikowaniu partykularnych wizji potrzeb i form ich zaspokojenia. Podobnie wysunięte na ich temat teorie nie są po prostu dane i dostępne w doświadczeniu jako ujawnione prawidłowości, ale pozostają wytwarzane w obrębie filozoficznie i historycznie uwarunkowanych systemów wiedzy. Pytań o prawdę/fałsz nie rozstrzyga tutaj niezależny od teorii świat procesów i przedmiotów, lecz są one związane ze standardami ustanowionymi w ramach określonych systemów wiedzy. Myślenie takie kwestionuje uprzywilejowanie „ważności” i „obiektywności” w stosunku do sensu, kwestię prawdy odnosi zaś do systemów znaczeń (Heidegger, 1994, s. 304-305; Foucault, 1981, s. 60-61). W efekcie politologiczne poznanie w dużym stopniu należy traktować w kategoriach wątpliwości, względności, co w konsekwencji powoduje, że prawda jest nie tyle osiągana i potwierdzana, ile intersubiektywnie uzgadniana. Ostatecznym trybunałem, przed którym staje teoria, jest społeczność uczonych oceniających przedkładane interpretacje. Ich adekwatność trzeba więc postrzegać w kategoriach stopnia, w jakim umożliwiają zrozumienie procesów politycznych. Z tego względu atrybutem badań staje się odmowa przyjęcia jakichkolwiek identyfikacji zakończonych, czyli ciągła niepewność i niepokój poznawczy. Choć światem polityki czasem rządzą prawidłowości, to równie istotne znaczenie mają pogłębiające wrażenie chaosu przypadki oraz kontekstowe i partykularne narracje. Siła poznania politologicznego 
powinna zatem polegać na sceptycznym stosunku do własnych odkryć i ciągłym ich kwestionowaniu (Bodio, 2003, s. 365).

\section{Interpretacja jako imperatyw badawczy politologa}

Aktywność polityczna ma charakter teleologiczny, ale zawsze osadzona jest w skonstruowanej i wyobrażonej wizji świata. Jej zrozumienie oznacza „ujawnienie sensu, jakie jednostkowe zjawisko posiada w historycznie określonym zespole sensów, znaczeń i wartości” (Kuderowicz, 1987, s. 85). Wszelkie próby całościowego poznania praktyk politycznych nie mogą więc sprowadzać się jedynie do wyjaśnień genetycznych (przyczynowych), funkcjonalnych (teleologicznych) czy kontekstowych (Nowicka, 2009, s. 126-129). Niezbędne jest ujawnienie wyobrażonej konstrukcji badanego fenomenu oraz wskazanie na warunkowe i wolicjonalne związki między przekonaniami a podejmowanymi działaniami. Subiektywnych wyobrażeń, ale także ich związku z aktywnością nie znamionuje konieczność przyczynowa i można ją poddać co najwyżej interpretacyjnej oraz narracyjnej formie wyjaśnień. W tym zaś względzie dążenie do wypracowania wiarygodnej interpretacji poprzez analizowanie, jak podmioty polityczne wytwarzają znaczenia w ramach struktur społecznych, nie oznacza próby stworzenia jednej, właściwej i niepodważalnej teorii. Wiedzę należy traktować tutaj jako swoiste dążenie oraz interakcję między konkurencyjnymi pomysłami. Jeśli rzeczywistość polityczna jest społecznie konstruowana, to celem politologicznej aktywności winno być dotarcie do wiarygodnych jej interpretacji (Postman, 2006, s. 185; Lenk, 1995, s. 9-31; Berger, Luckmann, 1983). Choć z istoty swojej będą one przygodne, gdyż rzeczywistość polityczna i jej kontekst dynamicznie ewoluują, to w danym czasie okażą się trafniejsze niż inne. Chodzi tu więc o zbudowanie najbardziej prawdopodobnego i zobiektywizowanego domysłu (Pinker, 2002, s. 30 i n.), który jednak nigdy nie będzie tym samym co interpretowana rzeczywistość.

W związku z powyższym badanie polityki uwzględniające konieczność podejścia interpretacyjnego winno być prowadzone ze świadomością pewnych ograniczeń poznawczych. Nie można bowiem ignorować indywidualnych predylekcji, nie do końca świadomych procesów emocjonalnych oraz zaburzeń osobowości, które przynajmniej w pewnym stopniu zakłócają wyważone sądy podmiotów, ich skłonność do wysłuchiwania wzajemnych racji i szukania porozumienia. Ujawniane słowa, deklaracje i gesty mogą jedynie częściowo odsłaniać to, co faktycznie determinuje indywidualne motywacje oraz interpretacje wartości (Dziubka, 2014, s. 96). W takiej sytuacji celem politologa może być co najwyżej próba zrozumienia, polegająca na uchwyceniu sedna lub znaczenia tego, co obserwowane. Jest to zadanie dalekie od konkretnych ustaleń statystyki i praw 
przyczynowych, a bliższe raczej dziedzinie języka oraz wewnętrznym relacjom wiążącym części tej dziedziny (Winch, 1995, s. 32).

W tym kontekście zasadniczą wartością interpretacjonizmu jest odrzucenie poglądu, że świat istnieje jedynie niezależnie od wiedzy o nim, a w poznaniu dostępne są człowiekowi czyste fakty. $\mathrm{Z}$ tego względu nie jest możliwe doświadczenie niezakłócone czy niezdeformowane w żaden sposób przez podmiot poznający. Nie da się więc wywieść przekonań i preferencji jednostek czy grup z obiektywnych faktów dotyczących ludzi, takich jak na przykład przynależność klasowa, rasa czy stanowisko w instytucji. To, że nie ma czystych doświadczeń, oznacza, że przekonań i preferencji nie można sprowadzać do roli zmiennych interweniujących. Interpretacja polega na odniesieniu do szerszej sieci znaczeń. Są one nie tylko konstytutywne dla ludzkich działań, ale i w swej naturze holistyczne (Bevir, Rhodes, 2006, s. 133-134, 283-284).

$\mathrm{Na}$ wysuwane interpretacje politologiczne składają się między innymi oceny opisowe, wyjaśnienia i generalizacje. Poddają się one ocenie w kategoriach zbliżonych do prawdy i fałszu, a więc ich wartość poznawcza nie jest jednakowa. Wysuwane koncepcje stają się tym bardziej wiarygodne, im mocniejodwołują się do kryteriów stosowanych w praktyce naukowej danej wspólnoty badaczy. Istotną rolę odgrywają tutaj kryteria dokładności, wyczerpującego charakteru, spójności i otwierania nowych możliwości badań. Tadeusz Klementewicz (2010, s. 321) zwraca uwagę na:

- jakość bazy informacyjnej i empirycznej, wiedzy faktograficznej czy danych statystycznych itp., które stanowią podwaliny wysuniętej narracji;

- znajomość i prawomocne zastosowanie odpowiednich metod badawczych, począwszy od reguł krytyki źródeł, metody reprezentacyjnej, po respektowanie reguł poprawności wnioskowań;

- respektowanie etyki zawodowej badania naukowego, głównie obiektywności i opisów neutralnych;

- otwarcie przedstawionych interpretacji, syntez, teorii na krytykę kompetentnych badaczy, respektujących metodę i etykę badań.

W efekcie interpretacje naukowe można więc odróżnić od nienaukowych. Ich obiektywizacja wyłania się z krytyki i porównania, choć wszystkie uznaje się za tymczasowe.

$\mathrm{Na}$ koniec warto jednak powtórzyć, że ujęcie integralne, nastawione na poznanie całościowe i koncentrujące się na wzajemnie dopełniającym charakterze zjawisk i procesów politycznych, nie może się ograniczać do interpretacji. Owszem, wymaga uwzględnienia subiektywno-narracyjnych aspektów polityki jako przedmiotu badań, ale jednocześnie nie powinno zignorować strukturalnych i materialnych jej wytworów, które kształtują sytuację podmiotów. Ponadto równie ważne jest uwzględnienie obiektywnych uwarunkowań przyrodniczych i gatunkowych, które także w kontekście przedmiotu badań politologa pełnią za- 
sadniczą funkcję. W efekcie przed świadomym badaczem staje niełatwe zadanie wykorzystania złożonego repertuaru narzędzi metodologicznych. Trudne tym bardziej, że nastawienie na specjalizację i badania wycinkowe wydaje się dzisiaj o wiele bardziej pragmatycznym rozwiązaniem. Należy jednak pamiętać, że zawsze będzie to swoista droga na skróty, która w najlepszym wypadku przyniesie co najwyżej częściowe odpowiedzi na zadane pytania.

\section{Literatura}

Archer, M.S. (2007). Making Our Way through the World: Human Reflexivity and Social Mobility. Cambridge: Cambridge University Press.

Archer, M.S. (2013). Człowieczeństwo. Problem sprawstwa, przeł. A. Dziuban. Kraków: Nomos.

Banaszak, G., Kmita, J. (1994). Społeczno-regulacyjna koncepcja kultury. Warszawa: Instytut Kultury.

Berger, P.L., Luckmann, T. (1983). Społeczne tworzenie rzeczywistości, przeł. J. Niżnik. Warszawa: PIW.

Berlin, I. (1991). Dwie koncepcje wolności, przeł. H. Bartoszewicz. Warszawa: Res Publica.

Bevir, M., Rhodes, R.A.W. (2006). „Teoria interpretacjonistyczna”. W: D. Marsh, G. Stoker (red.). Teorie i metody w naukach politycznych, przeł. J. Tegnerowicz. Kraków: Wydawnictwo Uniwersytetu Jagiellońskiego.

Blok, Z. (1998). Teoria polityki. Studia. Poznań: Wydawnictwo Uniwersytetu im. Adama Mickiewicza.

Bodio, T. (2003). „Politologia jako futurologia”. W: B. Kaczmarek (red.). Metafory polity$k i$, t. 2. Warszawa: Dom Wydawniczy Elipsa.

Brożek, B. (2013). „Hipoteza umysłu normatywnego”. Studia z Kognitywistyki i Filozofii Umystu, 7(2), s. 36-51.

Chmielewski, A. (2011). „Cząstki w przestrzeni: Charles Taylor i estetyka polityczna”. W: Ch. Garbowski, J.P. Hudzik, J. Kłos (red.). Charlesa Taylora wizje nowoczesności. Warszawa: Wydawnictwo Naukowe PWN.

Dilthey, W. (2004). Budowa świata historycznego w naukach humanistycznych, przeł. E. Paczkowska-Łagowska. Gdańsk: Słowo/Obraz Terytoria.

Dziubka, K. (2011). „Stylizacje podmiotowości i tożsamości w ujęciu indywidualizmu ekspresyjnego". W: A. Lisowska, J. Kurzępa (red.). Zachowania dysfunkcyjne - uwarunkowania spoteczne, kulturowe i polityczno-prawne oraz stosowane rozwiazania. Wrocław: Wydawnictwo Uniwersytetu Wrocławskiego.

Dziubka, K. (2014). „,Ponowoczesny człowiek publiczny i jego markery mentalno-kulturowe". Filo-Sofija, 24, s. 91-119.

Dziubka, K. (2015a). „Jak to jest być świadomym obywatelem?”. Filo-Sofija, 29, s. 107-134.

Dziubka, K. (2015b). „Myślenie polityczne jako proces mapowania świata życia”. W: E. Maj, E. Kirwiel, E. Podgajna (red.). Myśl polityczna w społeczeństwie informacyjnym. Lublin: Wydawnictwo UMCS. 
Fleischer, M. (2002). Teoria kultury i komunikacji, przeł. M. Jaworowski. Wrocław: Dolnośląska Szkoła Wyższa Edukacji Towarzystwa Wiedzy Powszechnej.

Foucault, M. (1977). Archeologia wiedzy, przeł. A. Siemek. Warszawa: PIW.

Foucault, M. (1981). „The Order of Discours”. W: R. Young (ed.). Untying the Text: A Post-Structuralist Reader. London: Routledge \& Kegan Paul.

Giddens, A. (2007). Socjologia, przeł. A. Szulżycka. Warszawa: Wydawnictwo Naukowe PWN.

Grabias, S. (1997). Język w zachowaniach społecznych. Lublin: Wydawnictwo UMCS.

Habermas, J. (1983). Teoria i praktyka, przeł. M. Łukasiewicz, Z. Krasnodębski. Warszawa: PIW.

Harari, N. (2017). Od zwierząt do bogów. Krótka historia ludzkości, przeł. J. Hunia. Warszawa: Wydawnictwo Naukowe PWN.

Heidegger, M. (1994). Bycie i czas, przeł. B. Baran. Warszawa: Wydawnictwo Naukowe PWN.

Julia, D. (1998). Słownik filozofii. Katowice: Książnica.

Karwat, M. (1980). Podmiotowość polityczna: humanistyczna interpretacja polityki w marksizmie. Warszawa: PWN.

Klementewicz, T. (2010). Rozumienie polityki. Zarys metodologii nauki o polityce. Warszawa: Dom Wydawniczy Elipsa.

Krakowiak, T. (2008). „Analiza dyskursu - próba nakreślenia pola badawczego”. W: A. Horolets (red.). Analiza dyskursu w socjologii i dla socjologii. Toruń: Wydawnictwo Adam Marszałek.

Kuderowicz, Z. (1987). Dilthey. Warszawa: Wiedza Powszechna.

Kumaniecki, K. (oprac.). (1986). Słownik łacińsko-polski. Warszawa: PWN.

Kurek, Ł. (2016). Dualizm przekonań. Kraków: Copernicus Center Press.

Lakoff, G. (2011). Nie myśl o słoniu. Jak język kształtuje politykę, przeł. A.E. Nita, J. Wasilewski. Warszawa: Oficyna Wydawnicza Łośgraf.

Lakoff, G., Johnson, M. (2010). Metafory w naszym $\dot{z} y c i u$, przeł. T.P. Krzeszowski. Warszawa: Aletheia.

Laska, A. (2012). „Politologiczne determinanty technokratyzacji polityki”. W: J. Golinowski, A. Laska (red.). Odsłony współczesnej polityki. Bydgoszcz: Wydawnictwo Uniwersytetu Kazimierza Wielkiego.

Laska, A. (2017). Teoria polityki. Próba ujęcia integralnego. Bydgoszcz: Wydawnictwo Uniwersytetu Kazimierza Wielkiego.

Latour, B. (2013). Nadzieja Pandory, przeł. K. Abriszewski. Toruń: Wydawnictwo Naukowe UMK.

LeDoux, J. (2000). Mózg emocjonalny: tajemnicze podstawy życia emocjonalnego, przeł. A. Jankowski. Poznań: Media Rodzina.

Lenk, H. (1995). Filozofia pragmatycznego interpretacjonizmu, przeł. Z. Zwoliński. Warszawa: Oficyna Naukowa.

Majone, G. (2004). Dowody, argumenty i perswazja w procesie politycznym, przeł. D. Sielski. Warszawa: Wydawnictwo Naukowe Scholar.

Nelson, K. i in. (1989). „Constructing a World”. W: K. Nelson (ed.). Narratives from the Crib. Cambridge: Harvard University Press.

Nowicka, E. (2009). Świat człowieka - świat kultury. Warszawa: Wydawnictwo Naukowe PWN. 
Nunan, D. (1993). Introducing Discourse Analysis. London: Penguin English.

Perelman, Ch. (1982). The Realm of Rhetoric. Notre Dame: University of Notre Dame Press.

Pinker, S. (2002). Jak działa umysł, przeł. M. Koraszewska. Warszawa: Książka i Wiedza.

Postman, N. (2006). Technopol. Triumf techniki nad kulturą, przeł. A. Tanalska-Dulęba. Warszawa: Muza.

Ramachandran, V.S. (2012). Neuronauka o podstawach człowieczeństwa. O czym mówi mózg?, przeł. E. Kołodziej-Józefowicz, A. i M. Binderowie. Warszawa: Wydawnictwo Uniwersytetu Warszawskiego.

Searle, J.R. (1999). Umysł, język, społeczeństwo, przeł. D. Cieśla. Warszawa: W.A.B.

Stankiewicz, W.J. (2003). Niezbędność teorii politycznej. Klasyczne pojęcia $w$ dobie relatywizmu. Wrocław: Ossolineum.

van Dijk, T.A. (2001). Badania nad dyskursem. W: T.A. van Dijk (red.). Dyskurs jako struktura i proces. Warszawa: Wydawnictwo Naukowe PWN.

Warchał, A. (2005). „Polityka jako noeza przeżywanego świata”. W: B. Kaczmarek (red.). Metafory polityki, t. 3. Warszawa: Dom Wydawniczy Elipsa.

Weber, M. (2004). „ «Obiektywność» poznania społeczno-naukowego i społeczno-politycznego". W: tegoż. Racjonalność, władza, odczarowanie, przeł. M. Holona. Poznań: Wydawnictwo Poznańskie.

Winch, P. (1995). Idea nauki o społeczeństwie i jej związki z filozofią, przeł. B. Chwedeńczuk. Warszawa: Oficyna Naukowa.

\section{Streszczenie}

Autor przypomina o potrzebie ujmowania polityki zarówno jako fenomenu obiektywnego, jak i subiektywnego. Postuluje, aby jej badanie łączyło podejście analityczno-empiryczne $\mathrm{z}$ interpretacją. $\mathrm{W}$ jego rozumieniu ta ostatnia nie jest tożsama $\mathrm{z}$ badaną rzeczywistością, lecz stanowi próbę obiektywizacji wiedzy. Instrumentalne i mechanistyczne ujmowanie procesów politycznych jest według niego całkowicie nieadekwatne, gdyż ignoruje rolę emocji, intencji, inteligencji, woli i świadomości człowieka. Badanie politologiczne nie może się jednak ograniczać do interpretacji. Równie ważne jest uwzględnianie strukturalnych i materialnych wytworów polityki, a także uwarunkowań przyrodniczych i gatunkowych. W rezultacie przed świadomym badaczem staje trudne zadanie integracji złożonego repertuaru narzędzi metodologicznych.

Słowa kluczowe: interpretacjonizm, teoria integralna, subiektywność polityki, narracyjność polityki, człowiek polityczny 